\title{
Plants Response to the Application of Vermicompost: A Review
}

\author{
Bewuket Gashaw \\ Wolkite University, College of Agriculture and Natural Resource, PO Box 07, Wolkite, Ethiopia
}

\begin{abstract}
Organic fertilizer has long been recognized in agriculture for maintaining soil fertility and used for maximizing plant growth and yield of plants. Vermicompost: organic fertilizer is now becoming an interesting approach and proven to be effective means of improving soil structure, enhancing soil fertility and increase crop yield. Plants growth is highly stimulated by vermicompost; because it contains the nutrients and other essential nutrients like phosphorus and potassium. Vermicompost can increase growth, flowering and yields of vegetable and ornamental crops, even in a small rate. The effects of vermicompost on plants are not solely attributed to the quality of mineral nutrition is provided but also to its other growth regulating components such as plant growth hormones and humic acids.
\end{abstract}

Keywords: Vermicompost, soil fertility, plant growth

DOI: $10.7176 / \mathrm{JNSR} / 9-3-06$

\section{Introduction}

The negative effects of chemical fertilizers and pesticides have shifted the interests of researchers towards use of organic fertilizer like vermicompost which can increase the production of crops and prevent them from harmful pests without polluting the environment (Joshi et al., 2014). Vermicompost are products derived from the accelerated biological degradation of organic wastes by earthworms and microorganisms. Earthworms consume and fragment the organic wastes into finer particles by passing them through a grinding gizzard and derive their nourishment from microorganisms that grow upon them. The process accelerates the rates of decomposition of the organic matter, alter the physical and chemical properties of the material, leading to a humification effect in which the unstable organic matter is fully oxidized and stabilized (Orozco et al., 1996). The end product commonly referred to as vermicompost is greatly humified through the fragmentation of the parent organic materials by earthworm sand colonization by microorganisms (Edwards and Neuhauser; Edwards, 1998).

Vermicompost are rich in bacteria, actinomycetes, fungi and cellulose-degrading bacteria (Werner and Cuevas, 1996). Tomati et al. (1983) reported that earthworm castings, obtained after sludge digestion, were rich in microorganisms, especially bacteria. Nair et al. (1997) compared the microorganisms associated with vermicompost with those in traditional composts. The vermicompost had much larger populations of bacteria (5.7 $\mathrm{x}$ 107), fungi (22.7 x 104) and actinomycetes (17.7 x 106) compared with those in conventional composts. Vermicompost are finely-divided mature peat-like materials with a high porosity, aeration, drainage and waterholding capacity and microbial activity which are stabilized by interactions between earthworms and microorganisms in a non-thermophilic process (Edwards and Burrows, 1988).

Vermicompost contains most nutrients in plant in available forms such as nitrate, phosphates and exchangeable calcium and soluble potassium (Orozco, 1996). Vermicompost prepared from animal waste sources, usually contained more mineral elements than commercial plant growth media, and many of these elements were changed to forms more that could be readily taken up by the plants, such as nitrates, exchangeable phosphorus, and soluble potassium, calcium, and magnesium (Edwards and Burrows, 1988). Similarly, Orozco et al. (1996) reported that coffee pulp, increased the availability of nutrients such as phosphorus, calcium and magnesium, after processing by Eisenia fetida.

Joshi et al. (2014) described vermicompost as an excellent soil amendment and a biocontrol agent through a number of studies along with the reasons which make it the best organic fertilizer and more eco-friendly as compared to chemical fertilizers. Therefore, the objective of this paper is to review the response of plants to the application of vermicompost.

\section{Literature Review}

\subsection{Characteristics of vermicompost}

Adhikary (2012) defined vermicompost as the excreta of earthworm which are capable of improving soil health and nutrient status. Vermicompost is a process by which all types of biodegradable wastes such as farm wastes, kitchen wastes, market wastes, bio-wastes of agro based industries, livestock wastes etc. are converted while passing through the worm-gut to nutrient rich vermicompost. Vermicompost is an excellent soil additive made up of digested compost. It has higher nutritional value than traditional composts. This is due to increased rate of mineralization and degree of humification by the action of earthworms (Albanell et al. 1988). Furthermore, it has high advantage in increasing soil fertility by improving soil physical characteristics. This is because vermicompost has high porosity, aeration, drainage, and water-holding capacity (Edwards and Burrows 1988). Nutrients such as 
nitrates, phosphates, and exchangeable calcium and soluble potassium in plant-available forms are also present in vermicompost (Orozco et al. 1996). In addition to this the author indicated that vermicompost increased $\mathrm{N}$ availability, C, P, K, Ca and Mg availability in the casts are found (Orozco et al. 1996).

\subsection{Vermicomposting process}

Vermicomposting is a decomposition process involving the joint action of earthworms and microorganisms (Aira et al. 2000). Microorganisms, particularly earthworms are used to enhance the process of waste conversion and produce a better product (Adhikary, 2012).

\subsection{Nutrients in vermicompost}

Vermicompost is an excellent soil additive made up of digested compost. Worm castings are much higher in nutrients and microbial life and therefore, are considered as a higher value product (Adhikary, 2012). Worm castings contain up to 5 times the plant available nutrients found in average potting soil mixes. Chemical analysis of the castings was conducted (Ruz, J. et al, 1992) and found that it contains 5 times the available nitrogen, 7 times the available potash and 1.5 times more calcium than that found in $15 \mathrm{~cm}$ of good top soil. In addition, the nutrient life is up to 6 times more in comparison to the other types of potting mixes. It is reported that phosphorous while passage through gut of worms is converted to the plant available form (Reinecke, A., et al. 1992.). Phosphorous is usually considered as a limiting element for plant growth. Therefore, any process that significantly increases phosphorous availability through plants and organic matter will be very important for agriculture. The average potting soil mixes that is found in the market are usually sterile and do not have a microbial population. The combination of nutrients and microbial

\subsection{Effect of vermicompost on plants}

Plants growth is highly stimulated by vermicompost; because it contains the nutrients and other essential nutrients like phosphorus and potassium (Fernández, L. et al., 2010). A number of field experiments have reported positive effects of even low application rates of vermicompost to crops (Norman and Clive, 2005). In tomato and okra vermicompost has increased the yield effectively (Suthar, S., 2010). Similarly, Sallaku et al., 2009 showed relative growth rate of cucumber (Cucumis sativus) seedlings was found to be significantly higher due to the application of vermicompost. Many studies also showed that combined application of vermicompost with the recommended inorganic fertilizer can increased yield in most crops. Tomato showed increment in yield with combined applications of vermicompost and 50\% of the recommended inorganic fertilizers (Kolte et al., 1999). Arancon et .al. (2002) reported significantly increased growth and yields of field tomatoes and peppers when vermicompost applied to field plots at rates of $20 \mathrm{t} / \mathrm{ha}$ and $10 \mathrm{t} / \mathrm{ha}$ and at rates of $10 \mathrm{t} / \mathrm{ha}$ and $5 \mathrm{t} / \mathrm{ha}$ compared with those receiving equivalent amounts of inorganic fertilizer. Ushakumari et al. (1999) reported that the yields of okra increased with the application vermicompost at the rate of $12 \mathrm{t} /$ ha together with $100 \%$ or $75 \%$ of the recommended fertilizer. Similarly, Athani et al. (1999) demonstrate that vermicompost applied at rates of $2 \mathrm{~kg} / \mathrm{plant}$ together with $75 \%$ of the recommended rate of inorganic fertilizers, promoted shoot production of bananas. A lower application rate of $2 \mathrm{t} /$ ha vermicompost plus recommended amounts of inorganic fertilizers, increased tomato yields to a level similar to those of tomatoes in soils treated with $4 \mathrm{t} / \mathrm{ha}$ vermicompost and $50 \%$ of the recommended rates of inorganic fertilizers (Patil et al., 1998). Potatoes produced the greatest marketable yields after amending the soils with $75 \%$ of the recommended inorganic fertilizers and $2.5 \mathrm{t} /$ ha vermicompost (Mrinal et al., 1998). Sunflowers gave most after soil treatments with $50 \%$ of the recommended application rates of inorganic fertilizer and $5 \mathrm{t} / \mathrm{ha}$ or $10 \mathrm{t} / \mathrm{ha}$ of vermicompost (Devi et al., 1998). Peas increased yields and production after amending soils with $100 \%$ of the recommended application rate of inorganic fertilizers, in combination with vermicompost produced from farm manures applied at rates of 10t/ha to soils (Ramachandra et al., 1998). Zende et al. (1998) reported increased yields of sugarcane after amending soils with vermicompost at rates of $5 \mathrm{t} / \mathrm{ha}$ together with $100 \%$ of the recommended application rate of inorganic fertilizers.

Studies reported better yield and growth in wheat crops applied with vermicompost. Yield of wheat was improved by more than $40 \%$ by the application of vermicompost fertilizer (Palanisamy, S., 1996). Studies made on the agronomic impacts of vermicompost on rice crops (Oryza sativa) reported greater population of nitrogen fixers, actinomycetes and mycorrhizal fungi inducing better nutrient uptake by crops and better growth (Kale, R.D., et al. 1992).

\subsection{Physico-chemical changes in soils in response to vermicompost applications}

The improvements in growth and yields of crops grown in potting media in greenhouses or in field soils that had been substituted or amended with vermicompost could be attributed to several factors. Vermicompost contribute to improvements in physico-chemical and biological characteristics of the planting media or field soils that favored better plant growth. However, the changes in $\mathrm{pH}$ reported contrasted with those from the work of Tyler et al. (1993) who reported increases in substrate $\mathrm{pH}$ in response to increasing concentrations of composted turkey litter 
added to a plant container medium. Electrical conductivity in pig manure vermicompost increased linearly as a result of increasing salt concentration (Atiyeh et al., 2001a, b).

Amounts of soil N, P and K increased significantly after incorporating vermicompost into soils (Venkatesh et al., 1998, Sreenivas et al., 2000). In soils planted with strawberries, the amounts of total extractable N, microbial biomass $\mathrm{N}$ and dissolved organic $\mathrm{N}$ were statistically similar, between all treatments at the end of the growth cycle of strawberries but there were more orthophosphates in those soils that received vermicompost treatments than in soils treated with inorganic fertilizers. Maheswarappa et al. (1999) reported increased amounts organic carbon, improvements in $\mathrm{pH}$, decreased bulk density, improved soil porosities and water-holding capacities, increased microbial populations and dehydrogenase activity of soils in response to vermicompost treatments.

\subsection{Plant growth regulator production in vermicompost}

There is a very substantial body of evidence demonstrating that microorganisms, including bacteria, fungi, yeasts, actinomycetes and algae, are capable of producing plant growth hormones and plant growth regulators (PGRs) such as auxins, gibberellins, cytokinins, ethylene and abscisic acid in appreciable quantities (Arshad and Frankenberger, 1993). There have been many studies of the production of plant growth-regulating substances by mixed microbial populations in soil, but there are relatively few investigations into their availability to plants, and persistence and fate in soils or documenting reliably their effects on plant growth (Arshad and Frankenberger, 1993).

Norman and Clive (2005) reviewed that PGRs can be taken up by plants from soil in sufficient quantities to influence plant growth. It was shown that auxins produced by Azospirillum brasilense could affect the growth of graminaceous plants (Kucey, 1988). Gibberellins can also influence plant growth and development (Arshad and Frankenberger, 1993). Increased vigor of seedlings has been attributed to microbial production of cytokinins by Arthrobacter and Bacillus spp in soils (Jagnow, 1987). Since the process of vermicomposting increases microbial diversity and activity, it is possible that vermicompost could be a definitive source of plant growth regulators produced by interactions between microorganisms and earthworms, which could contribute significantly to enhancement of plant growth, flowering and yields. The presence of plant growth regulating substances in the tissues of Aporrectodea caliginosa, Lumbricus rubellus and Eisenia fetida was confirmed by Nielson (1965) who isolated indole substances from earthworms and reported increases in growth of peas due to the earthworm extracts.

Vermicompost originating from animal manure, sewage sludges or paper-mill sludges have all been reported to contain large amounts of humic substances (Senesi et al., 1992; Garcia et al., 1995; Masciandaro et al., 1997; Elvira et al., 1998). Studies of the effects of humic substances on plant growth, under conditions of adequate mineral nutrition, have consistently produced in positive growth effects (Chen and Aviad, 1990).

\subsection{Suppression effect of vermicompost}

Shakir and Mikhal (2004) reported that vermicompost can suppress the incidence of plant pathogens such as Pythium, Rhizoctonia and Verticillium significantly, by general or specific suppression mechanisms. They also demonstrated that vermicompost applied to soils have considerable influence on the trophic structure of nematode populations, significantly suppressing plant parasitic species populations. Greenhouse experiments have shown that low substitutions of vermicompost into soil-less plant growth media can decrease the amounts of feeding and damage by sucking pests such as aphids and mealy bugs and chewing pests such as caterpillars.

Studies showed organic amendments can suppress plant diseases (Lazarovitis et al., 2000 and Fikre et al., 2001). Nkamura (1996) reported suppression of Plasrnodiophara brassicae, Phytophthora nicotianae (tomato late blight), and Fusarium lycopersici (tomato fusarium wilt) by vermicompost. Szczech (2002) reported suppression of Fusarium lycopersici, as well as Phytophthora nicotianae on tomatoes, by vermicompost. Rodriguez et al. (2000) demonstrated general suppression of fungal diseases of gerbera plants such as Rhizoctonia solani, Phytophthora drechsleri and Flisarium oxysponlm by the incorporation of vermicompost into the growth media. Studies by Nakasone et al. (1999) showed that aqueous extracts of vermicomposts inhibited the mycelial growth of Botrytis cinerea, Sclerotinia sclerotiorum, Corticium rolfsii, Rhizoctonia solani and Fusarium oxysporum.

\subsection{Effect of vermicompost on plant diseases}

Many studies have demonstrated the effectiveness of vermicompost in providing protection against various plant diseases (Chaoui, 2002; Arancon, 2002). Various studies have demonstrated the effectiveness of vermicompost in providing protection against various plant diseases (Moradi et al., 2014). In vermicomposting the active component involved in the biodegradation and conversion process during composting is the resident microbial community, among which fungi play a very important role (Wiegant, 1992).

\section{Summary and Conclusions}

The use of organic matter such as animal manures, human waste, food wastes, yard wastes, sewage sludge and composts has long been recognized in agriculture as beneficial for plant growth and yield and the maintenance of 
soil fertility. Vermicomposting, the new approaches to the use of organic amendments in farming have proven to be effective means of improving soil structure, enhancing soil fertility and increasing crop yields.

Vermicompost can increase growth, flowering and yields of vegetable and ornamental crops, even in a small rate. The effects of vermicompost on plants are not solely attributed to the quality of mineral nutrition is provided but also to its other growth regulating components such as plant growth hormones and humic acids. Furthermore, the application of vermicompost in the field enhances the quality of soils by increasing microbial activity and microbial biomass which are key components in nutrient cycling, production of plant growth regulators and protecting plants soil-borne disease and arthropod pest attacks.

\section{References}

Adhikary. S. 2012. Vermicompost the strong of organic gold: A review. Agriculture \& Ecological Research Unit, Biological Sciences Division, Indian Statistical Institute, Kolkata, India. vol.3, No.7, 905-917 (2012) http://dx.doi.org/10.4236/as.2012.37110

Aira M, Monroy F, Dominguez J, Mato S (2000) How earthworm density affects microbial biomass and activity in pig manure. Eur J Soil Biol 38:7-10.

Albanell E, Plaixats J, Cabrero T (1988) Chemical changes during vermicomposting (Eisenia fetida) of sheep manure mixed with cotton industrial wastes. Biol Fertil Soils 6:266-269.

Arancon N.Q., Edwards, C.A., Bierman, P., Metzger, J., Lee, S., Welch, C. 2002. Applications of vermicomposts to tomatoes and peppers grown in the field and strawberries grown unger high plastic tunnels. Proceedings of the International Earthworm Symposium, Cardiff Wales. September 2002.

Arancon NQ, Edwards CA and Lee S. 2002. Management of plant parasitic nematode populations by use of vermicomposts.Proc.Brighton Crop Prot. Conf. - Pests and Diseases. 8B-2: 705-716.

Arshad M. and Frankenberger W.T. Jr. 1993. Microbial Production of Plant Growth Regulators. In Soil Microbial Ecology: Applications in Agricultural and Environmental Management. Ed. F. B. Metting Jr. Marcell Dekker, New York, Basel, Hong Kong 307.

Athani S.I., Hulamanai N.C., and Shirol A.M. 1999. Effect of vermicomposts on the maturity and yield of banana. South Indian Horticulture. 47: 1-6, 4-7.

Atiyeh R.M., Arancon N.Q., Edwards C.A., and Metzger, J.D. 2001a. The influence of earthworm-processed pig manure on the growth and productivity of marigolds. Bioresource Technology. 81: 103-108.

Atiyeh R.M., Edwards C.A., Subler S., and Metzger J.D. 2001b. Pig manure vermicomposts as a component of a horticultural bedding plant medium: effects on physicochemical properties and plant growth. Bioresource Technology, 78: 11-20.

Chaoui H, Edwards CA, Brickner A, Lee S and Arancon NQ. 2002. Suppression of the plant parasitic diseases: Pythium(damping off), Rhizoctonia(root rot) and Verticillium(wilt) by vermicompost. Proc. Brighton Crop Prot. Conf. - Pests and Diseases, 8B-3: 711-716.

Chen Y. and T. Aviad. 1990. Effects of humic substances on plant growth. In: MacCarthy, P., C.E. Clapp, R.L. Malcolm and P.R. Bloom (eds) Humic Substances in Soil and Crop Sciences: Selected Readings. ASA and SSSA, Madison, Wisconsin, USA, 161-186.

Devi D., Agarwal S.K., and Dayal, D. 1998. Response of sunflower (Helianthus annuus) to organic manures and fertilizers. Indian Journal of Agronomy. 43(3): 469-473.

Edwards C. A. and Burrows I. 1988. The potential of earthworm composts as plant growth media. In Earthworms in Environmental and Waste Management Ed. C. A., Neuhauser, SPB Academic Publ. b.v. The Netherlands. 211-220.

Edwards C.A. (Ed). 1998. Earthworm Ecology. CRC Press Boca Raton. 389 pp

Elvira C., L. Sampedro E. Benitez and R. Nogales. 1998. Vermicomposting of sludges from paper mill and dairy industries with Eisenia andrei: a pilot-scale study. Bioresource Technology, 63: 205-211.

Ferna'ndez-Luquen o F, Reyes-Varela V, Mart'ınez-Sua'rez C, Salomo' n-Herna'ndez G, Ya'n ez-Meneses J, Ceballos- Ram'irez JM, Dendooven L (2010) Effect of different nitrogen sources on plant characteristics and yield of common bean (Phaseolus vulgaris L.) Bioresour Technol 101(1):396-403.

Fikre H, Sandhu KS, Singh P., 2001. Management of white rot pea through organic amend me fungicides. Plant Dis Res, 16: 193-197.

Garcia C., B. Ceccanti, G. Masciandro and T. Hernandez. 1995. Phosphatase and $\beta$ glucosidase activities in humic substances from animal wastes. Bioresource Technology, 53:79-87.

Grappelli A., E. Galli and U. Tomati. 1987. Earthworm casting effect on Agaricus bisporus fructification. Agrochimica, 21: 457-462.

Jagnow G. 1987. Inoculation of cereal crops and forage grasses with nitrogen-fixing rhizosphere bacteria. Possible causes of success and failure with regard to yield response--a review. Z. Pflanzenerahr. Bodenkol., 150: 361368.

Joshi. R., J.Singh and A.P.Vig. 2014.Vermicompost as an effective organic fertilizer and biocontrol agent: effect 
on growth, yield and quality of plants. Rev Environ Sci Biotechnol. DOI 10.1007/s11157-014-9347-1.

Kale, R.D., Mallesh, B.C., Kubra, B. and Bagyaraj, D.J. (1992) Influence of vermicompost application on the available macronutrients and selected microbial popula- tions in a paddy field. Soil Biology and Biochemistry, 24, 1317-1320. doi:10.1016/0038-0717(92)90111-A

Kolte U.M., Patil A.S. and Tumbarbe A.D. 1999. Response of tomato crop to different modes of nutrient input and irrigation. Journal of Maharashtra Agricultural Universities, 14: 1, 4-8.

Kucey R. M. N. 1988. Phosphate-solubilizing bacteria and fungi in various cultivated and virgin Alberta soils. Can. J. Soil Sci., 63, 671-678

Masciandaro G., B. Ceccanti and C. Garcia. 1997. Soil agro-ecological management: fertirrigation and vermicompost treatments. Bioresource Technology, 59: 199-206.

Moradi. H. Fahramand. M, Sobhkhizi1. A., Adibian. M, Noori1 M., abdollahi. S. and Rigi. K. 2014. Effect of vermicompost on plant growth and its relationship with soil properties. Intl J Farm \& Alli Sci. Vol., 3 (3): $333-338,2014$

Mrinal S., Rajkhowa D.J., and Saikia M. 1998. Effect of planting density and vermicomposts on yield of potato raised from seedling tubers. Journal of the Indian Potato Association. 25:3-4, 141-142.

Nair S.K., Naseema A, Meenakumari S.K., Prabhakumari P. and Peethambaran C.K.1997. Microflora associated with earthworms and vermicomposting. J. Trop. Agric. 35: 93-98.

Nakasone AK, Bettiol W, de Souza.RM., 1999. The effect of water extracts of organic matter on plant pathogens. Summa Phytopathol25: 330-335.

Nielson R. L. 1965. Presence of plant growth substances in earthworms demonstrated by paper chromatography and the Went pea test. Nature Lond. 208: 1113-1114.

Norman Q. Arancon and Clive A. Edwards. 2005. Effects of Vermicomposts on Plant Growth. Paper presented during the International Symposium Workshop on Vermi Technologies for Developing Countries (ISMVT 2205), November 16-18. Los Banos, Philippines.

Orozco SH, Cegarra J, Trujillo LM, Roig A (1996) Vermicomposting of coffee pulp using the earthworm Eisenia fetida: effects on $\mathrm{C}$ and $\mathrm{N}$ contents and the availability of nutrients. Biol Fertil Soils 22:162-166

Palanisamy, S. (1996) Earthworm and plant interactions. ICAR Training Program, Tamil Nadu Agricultural University, Coimbatore.

Patil M.P, Humani N.C., Athani S.I. and Patil M.G. 1998. Response of new tomato genotype Megha to integrated nutrient management. Advances in Agricultural Research in India 9: 39-42.

Ramachandra R., Reddy M.A.N., Reddy Y.T.N., Reddy N.S., Anjanappa M., and Reddy R. 1998. Effect of organic and inorganic sources of NPK on growth and yield of pea (Pisum sativum). Legume Research 21: 1, 57-60.

Reinecke, A., Viljoen, S.V. and Saayman, R. 1992. The suitability of Eudrilus eugenie, Perionyx excavatus and Eisenia fetida (Oligochaeta) for vermicomposting in southern Africa in terms of their temperature requirements. Soil Biology and Biochemistry, 24, 1295-1307 doi:10.1016/0038-0717(92)90109-B

Rodriguez JA, Zavaleta E, Sanchez P, Gonzalez H. 2000. The effect of vermicomposts on plant nutrition, yield and incidence of root and crown rot of gerber a (Gerberajamesonii H. Bolus). Fitopatol35: 66-79.

Ruz-Jerez, B.E., Ball, P.R. and Tillman, R.W. 1992. Laboratory assessment of nutrient release from a pasture soil receiving grass or clover residues, in the presence or absence of Lumbricus rubellus or Eisenia fetida. Soil Bi- ology and Biochemistry, 24, 1529-1534. doi:10.1016/0038-0717(92)90145-N

Senesi N., C. Saiz-Jimenez and T.M. Miano. 1992. Spectroscopic characterization of metal-humic acid-like complexes of earthworm-composted organic wastes. The Science of the Total Environment, 117/118, 111120

Shakir S. H. and W.Z.A. Mikhal. 2004. The influence of vermicompost on plant growth and pest incidence soil zoology for sustainable Development in the 21th Century. Cairo.

Sreenivas C., Muralidhar S., and Rao M.S. 2000. Vermicomposts: a viable component of IPNSS in nitrogen nutrition of ridge gourd. Annals of Agricultural Research. 21: 108-113.

Suthar, S. (2010) Vermicompost: An environmentally safe, economically viable and socially acceptable nutritive fer- tilizer for sustainable farming; In: Sinha, R.K., et al., Eds., Special Issue on Vermiculture Technology, Journal of En- vironmental Engineering, Inderscience Publishing, Olney.

Szczech M. 2002. Induction of systemic resistance in radish by pseudomonads. developing iri vermicompostsamended substrate. Phytopathol Polonica 24: 57-66.

Tomati U. and Galli E. 1995. Earthworms, Soil Fertility and Plant Productivity. In: Proc. Int. Coll. on Soil Zool. Acta Zool. Fenn. 196: 11-14

Tomati U., Grappelli A., and Galli E. 1983. Fertility factors in earthworm humus. Proc. Int. Symp. Agric. Environ. Prospects in Earthworm Farming. Publication Ministero della Ricerca Scientifica e Technologia, Rome, 4956.

Tyler H.H., Warren S.L., bilderback T.E., and Fonteno W.C. 1993. Composted turkey litter: I Effect on physical 
and chemical properties of pine bark substrate. Journal of Environmental Horticulture. 11: 131-136.

Ushakumari K., Prabhakumari P., and Padmaja P. 1999. Efficiency of vermicomposts on growth and yield of summer crop okra (Abelmoschus esculentus Moench). Journal of Tropical Agriculture. 37: 87-88.

Venkatesh, Patil P.B., Patil C.V., and Giraddi R.S. 1998. Effect of in situ vermiculture and vermicomposts on availability and plant concentration of major nutrients in grapes. Karnataka Journal of Agricultural Sciences. 11: $117-121$.

Werner M. and Cuevas, R. 1996. Vermiculture in Cuba. Biocycle. Emmaus, PA., JG Press. 37: 61-62.

Wiegant WMA. 1992. simple method to estimate the biomass of thermophilic fungi in composts.Biotech Tech, 5: $421-426$. 